\title{
Dr. Mathilde Krim: A Scientist and Her Fellowship Legacy
}

\author{
Marcella Flores and Rowena Johnston
}

\begin{abstract}
On January 15, 2018, the world lost Dr. Mathilde Krim, a woman who changed the life of every person who has ever worked in HIV research. Variously remembered as a humanitarian, a socialite, a philanthropist, and a political activist, Dr. Krim was first and foremost a scientist. We highlight her pioneering research in fetal sex determination, as well as her activism during the unfolding AIDS epidemic, which culminated in the cofounding of amfAR, the Foundation for AIDS Research. Finally, we provide an analysis of the award named in honor of her inspirational leadership, the Mathilde Krim Fellowships in Basic Biomedical Research, which aims to catapult the careers of exceptional, early-stage researchers in the HIV/AIDS field. We follow applicants through the two-tier application process and dissect what defines a successful applicant at each stage. Through the Krim Fellowships, we hope to ensure that a new generation of HIV scientists can realize amfAR's goal of ending the AIDS epidemic.
\end{abstract}

Keywords: Krim Fellowships, fellowships, Mathilde Krim

\section{How Dr. Krim Came to be an AIDS Pioneer}

O N JANUARY 15, 2018, THE WORLD LOST a woman who changed the life of every person who has ever worked in HIV research.

It is a testament to the many sides of Dr. Mathilde Krim that she is variously remembered as a humanitarian, a socialite, a philanthropist, and a political activist. She was an ardent supporter of the nascent state of Israel, serving briefly as a gunrunner for the Irgun. She was friends with presidents and Hollywood stars, and hosted a birthday after-party for President Kennedy the same evening Marilyn Monroe serenaded him with her infamous rendition of the "Happy Birthday" song. She and her husband Arthur B. Krim donated millions of dollars to more than a hundred organizations, supporting causes such as animal welfare, the environment, human rights for racial and sexual minorities, cultural and architectural preservation, policy and advocacy, particularly for disadvantaged people, and a range of medical causes, including AIDS. She served on the President's Committee on Mental Retardation, reported to Congress on the history of cancer research, and provided frequent Congressional testimony on HIV/AIDS.
However, first and foremost, Dr. Mathilde Krim was a scientist. She was a laboratory researcher who would garner over 1,300 citations, working first in Switzerland, then in Israel, and finally in New York City. She began her publishing career in 1950 at the Weizmann Institute, where she produced, under her previous married name, Danon, one of the first electron micrographic images of a chromosome ${ }^{1}$ before moving on to fetal sex determination, a topic on which she published 10 articles in 3 years. ${ }^{2-11}$ Her 1956 Science article titled, "The diagnosis of sex before birth using cells from the amniotic fluid," ${ }^{\circ}$ was published just 1 month after the Nature article by a Danish group that would be credited with developing the technique. ${ }^{12-14}$ In 1959, Dr. Krim's colleague and frequent collaborator, Dr. Leo Sachs, developed a technique ${ }^{15}$ to study mammalian tumor viruses in vitro. A few months later, Dr. Krim expanded this work to include the study of these viruses in vivo. ${ }^{16}$ More work quickly followed, including a 1960 Nature article,${ }^{17}$ delving into the relationship between viruses and cancer in mammals, and documenting tumor induction by virus and virus production by tumor cells, as well as transmission between mouse littermates, from infant to mother and from mother to the litter. Thus was born her enduring interest in the

Department of Research, amfAR, New York, New York.

(C) Marcella Flores and Rowena Johnston 2018; Published by Mary Ann Liebert, Inc. This Open Access article is distributed under the terms of the Creative Commons Attribution Noncommercial License (http://creativecommons.org/licenses/by-nc/4.0/) which permits any noncommercial use, distribution, and reproduction in any medium, provided the original author(s) and the source are cited. 
relationship between viruses and cancer, and ways to treat them, leading to her intense interest in the 1970s in interferon as a treatment modality.

In the same year that a team of French researchers isolated a new retrovirus from a patient with AIDS-1983-Dr. Krim's expertise on a variety of cancers as well as viruses was called upon in the case of several patients with Kaposi's sarcoma at Memorial Sloan-Kettering Cancer Center, where she was head of the interferon laboratory. Before the end of that year, 4,661 AIDS cases and 2,085 AIDS-related deaths had been recorded in the United States. In the absence of any meaningful response from the federal government to a disease that primarily struck young gay men, Dr. Krim founded the AIDS Medical Foundation, the first private organization dedicated to supporting research on AIDS. It would be another 2 years before President Reagan would even acknowledge the existence of AIDS, and a further 2 years before he would give a speech on the topic (at an amfAR event in Washington, DC).

By this stage of her life, Dr. Krim possessed a formidable accumulation of expertise, credibility, and connections, making her uniquely qualified to lead the charge against the unfolding epidemic. As Dr. Kenneth Mayer of Harvard Medical School and Fenway Health, a member of amfAR's Program Advisory Council and a former trustee, once observed, "I was extremely impressed with the unique combination of grace, élan, and social activism of this remarkable woman.... I thought to myself that if Dr. Krim did not exist, someone would have to invent her." Dr. Krim's scientific knowledge enabled her to speak with authority about the medical complexities of the frightening new disease. Her wartime exposure to footage of the Nazi death camps had instilled in her a profound empathy for those facing discrimination. Her association with Hollywood stars gave her the power to bring attention to AIDS, and her political connections gave her the clout to advocate rational, evidencebased public health policies.

Dr. Krim wasted little time in putting her skills and her rolodex to use. She testified before Congress on several occasions, and brought attention to the issue in interviews. "Physicians are very hesitant to announce a catastrophe and I said, it has to be said... otherwise the federal government will not pay attention. So I called as many people as I could in Washington to ask for financial support, but I got the usual stupid answer-nobody can fund it," she recalled in the 2013 documentary The Battle of amfAR.

Federal funding for AIDS research had not yet caught up to the reality of the disease. In 1982, NIH spent \$3.4M (equal to approximately $\$ 8.9 \mathrm{M}$ in 2018 dollars), which rose to $\$ 21.7 \mathrm{M}$ (equal to approximately $\$ 54.8 \mathrm{M}$ today) the following year, ${ }^{18}$ still woefully inadequate in the context of an almost entirely uncharted disease with a devastating mortality rate.

In 1985, Dr. Krim joined forces with Elizabeth Taylor, a very different, but no less indomitable woman, who said, "I was made so aware of this huge, loud silence regarding AIDS that I finally thought to myself, 'Bitch, do something yourself!', Together they formed amfAR to fill the gap in research funding. As luck would have it, they discovered that congressmen who wanted to be photographed with Elizabeth Taylor showed a sudden eagerness to support AIDS research at the federal level. Together, and with the assistance of Senator Edward M. Kennedy and others, the two women helped get the HOPE Act of 1988 and the Ryan White CARE Act of
1990 passed, ensuring funding for AIDS education, prevention, research, testing, and care. In 1988, the NIH spent \$473.3M on AIDS (around \$1B in 2018 dollars).

During the first 3 years of amfAR, when the virus was still sometimes known as human T-lymphotropic virus III or lymphadenopathy associated virus, grantees-some of whom are still active in HIV research-pursued a range of studies that today seem dated in some cases, prescient in others. There were grants to study antibody and $\mathrm{T}$ cell responses, vaccines and antivirals, perinatal infection and heterosexual transmission, central nervous system infection, and, reflective of the opportunistic co-infections that were rampant in those times, efforts to understand and treat Mycobacterium avium complex, pneumocystis carinii pneumonia, and toxoplasmosis. There were also studies related to public health, civil liberties and medical care costs, prevention pilot studies for at-risk youth, public opinion surveys, and educational efforts directed toward specific populations. There was so much yet to learn.

Dr. Krim served as chair of the amfAR board until 2007. During her tenure, amfAR funded more than 2,200 biomedical, social/behavioral, policy, education, and international projects, with outcomes that helped support the development of antiretroviral therapy, prevention of mother-to-child transmission, DNA vaccines, community-based clinical trials, and an international observational database. amfAR's research and advocacy were instrumental in achieving landmark policy advances, including the NIH Revitalization Act of 1993, and the establishment of the AIDS Drug Assistance Program (ADAP) to help low-income Americans cover the high cost of HIV treatment.

\section{Krim Fellowships}

To honor Dr. Krim's inspirational leadership and tireless efforts, amfAR inaugurated the Mathilde Krim Fellowships in Basic Biomedical Research. Nine young researchers received the first Krim Fellowships in January 2008. In total, 53 researchers have received Krim Fellowships to date. The goal was and continues to be to provide funding to exceptional, early-stage researchers in the HIV/AIDS field, and to facilitate their transition to a productive and independent longterm career in biomedical HIV/AIDS research, in an environment that offers scarce funding opportunities for career development. Indeed, the largest funder of basic science in the world, the NIH, has awarded just 23 new K99 awards in HIV biomedical sciences since 2008.

Identifying exceptional scientists among a pool of excellent researchers is a monumental and humbling task, yet one that is required of every funding agency, conference organizing committee, and university search and tenure committee. To inform these decisions, amfAR applies standard measures of scientific productivity and significance that are widely used in academia, including a candidate's publication record, the number of citations, impact factors of the publishing journals, and h-index.

The Letter of Intent (LOI) stage of the Krim Fellowship application aims to identify researchers with a high likelihood of promotion to an independent position following the fellowship. Thus, the first step is to determine whether the publication history of the applicant would support the candidate's independence within 2 years. An analysis of Krim Fellows from previous years has shown that, indeed, LOI 
applicants who were invited to submit full applications, stage two, had a statistically significant average h-index of 9.9, nearly 3 points higher than those who did not proceed to the second stage. For comparison, assistant professors in NYU's department of immunology have an h-index of 18.8, while associate professors have an average h-index of 32. Further consideration is also given to whether the applicant is largely first author, middle author, or, in some cases, last author on the publications, as well as the number of scientific talks and posters she or he has presented.

Successful LOI applicants are invited to submit full applications during the second stage of the application process. At this stage, when all candidates have comparably substantial publication records, factors such as sound science and appropriateness of the fellowship for the applicant's career separate candidates who are awarded fellowships. Our analysis of previous Krim Fellowship applicants shows that $81 \%$ of unsuccessful applicants invited to submit a full application lacked a cohesive research plan. The problems ranged from poor grantsmanship to providing insufficient detail to proposing only incidental rather than potentially important research. Because a fellowship provides protected time in a scientist's career, during which they are expected to make contributions that distinguish them within their field, reviewers are also looking for proposed research that differentiates applicant from mentor. Reviewers frequently comment on whether the proposed research "carves a niche" for the applicant, rather than furthering the mentor's career.

Finally, successful candidates are also those for whom the fellowship comes at an appropriate time in her or his career. An applicant on the cusp of considerable scientific impact will benefit more from the protected time offered by the fellowship than one with a steadier track record of contributions, whose productivity will be merely maintained during the fellowship time. The potential to catapult a career is a factor that is commonly raised during review sessions. Nearly $40 \%$ of unsuccessful applicants applied too late in their career or had received multiple fellowships, in which case another one might have only incremental benefits. Consistently, amfAR's Krim Fellows have been early-stage scientists with strong publication records, proposing valuable research with the potential to impact the field during the 2 years of protected time offered by the fellowship.

\section{Following in Dr. Krim's Footsteps}

Success can have many guises. While most Krim Fellows have gone on to pursue careers in academia, some have left to work in industry, where they maintain their commitment to HIV by supporting drug discovery and the development of modeling strategies for HIV treatment and cure. Others have chosen to redefine the leading edge of research and development, moving to companies such as X, Google's moonshot laboratory.

What is clear is that the Krim Fellowship program has been a highly successful propagator of exceptional talent. A former Krim Fellow, for example, who has become a leader in CD4 mimetics and was recently featured as a TEDx speaker, has gone on to mentor his own Krim Fellow. Another former Fellow, who published 12 articles during his 2-year fellowship, is mentoring a current Krim Fellow, soon to be starting her own research laboratory.
The impact on science that amfAR's Krim fellows have had includes the further refinement and optimization of SOSIP trimers-stabilized Env trimers, the development of which reinvigorated the vaccine world, and the creation of innovative tools such as a CRISPR-based, high-throughput human geneediting platform. Krim Fellowships have also in some cases had an effect on institutional infrastructure. Seeing the beneficial effect of early career support provided by a Krim Fellowship, one European research institute created professional research positions to support post-fellowship scientists and has now filled five such positions in addition to the former Krim Fellow.

Other fellows let experiments lead the way. When results from other medically relevant viruses developed more quickly, a shift to transfer knowledge from HIV to Dengue and Zika virus, as well as the building of collaborations to support the transfer, led a former Krim Fellow to obtain a permanent position at the prestigious Pasteur Institute.

\section{Conclusion}

Most of the Krim Fellows amfAR has funded were not yet born when AIDS was first described in $1981 .^{19}$ They have planned for themselves a career aimed at understanding and conquering one of the most devastating infectious agents ever to afflict humankind. We, who each left the academic path at the very career inflexion point that Krim Fellowships support, certainly understand the challenges associated with the academic career choice.

An individual's life can mean different things to different people. Extraordinary people like Dr. Krim can affect countless lives in often unforeseen ways. We have many photos of Dr. Krim in our amfAR offices. Among our favorites are Dr. Krim working in her laboratory at Memorial Sloan-Kettering, and another in which she looks pleased, but bemused, while receiving the Presidential Medal of Freedom from President Clinton in 2000. Perhaps the best is a photo in which she, looking every part the society lady she was, is sporting an enormous smile, while enjoying the incongruity of riding in a Gay Pride parade with Mr. Leather.

What we remember most about Dr. Krim is her passionate and unrelenting advocacy of science and the implementation of evidence-based policies. While we lost Dr. Krim in January of this year, the work she enabled us to do continues. In 2014, one of us had the good fortune to co-author an article with Dr. Krim for this journal. In it, we discussed our vision for ending AIDS. We can think of no more fitting tribute than to imagine a role for amfAR's Krim Fellows and their research findings in realizing this vision.

\footnotetext{
"Dr. Krim's exemplary scientific achievements and her exceptional personality will be an inspiration for several generations of biomedical scientists. For me, it has been a privilege to be the recipient of a fellowship named after Dr.
} Krim."

\section{Stylianos Bournazos \\ Krim Fellow ' 16}

Rockefeller University, New York, NY

\section{Author Disclosure Statement}

No competing financial interests exist. 


\section{References}

1. Danon M, Guyénot E, Kellenberger E, Weigle J: Electron micrograph of a chromosome of triton. Nature 1950;165: 33.

2. Serr D, Sachs L, Danon M: The diagnosis of sex before birth using cells from the amniotic fluid (a preliminary report). Bull Res Counc Isr 1955;5B:137-138.

3. Sachs L, Danon M: Antenatal identification of hereditary disorders. The Lancet 1956;267:1013.

4. Sachs L, Danon M: Possibility of prenatal diagnosis of sex in cattle and sheep. Nature 1956;178:1402-1403.

5. Sachs L, Feldman M, Danon M: Prenatal identification of blood-group antigens. The Lancet 1956;268:356.

6. Sachs L, Serr D, Danon M: Prenatal diagnosis of sex using cells from the amniotic fluid. Science 1956;123: 548.

7. Sachs L, Serr D, Danon M: Analysis of amniotic fluid cells for diagnosis of foetal sex. Br Med J 1956;2:795-798.

8. Danon M, Sachs L: Sex chromosomes and human sexual development. The Lancet 1957;270:20-25.

9. Sachs L, Danon M: The diagnosis of the sex chromosomes in human tissues. Genetica 1957;28:201-216.

10. Danon M: The Sex Chromosomes and the Development of Human Intersexes. William Heinemann Medical Books, London, 1958.

11. Sachs L, Danon M: The Genetic Implications of Nuclear Sexing. William Heinemann, London, 1958.

12. Fuchs F, Riis P: Antenatal Sex Determination. Nature 1956; 177:330.
13. Brind'Amour K: Amniocentesis. Embryo Project Encyclopedia. Available at http://embryo.asu.edu/handle/ 10776/1796 (2008), accessed May 1, 2018.

14. Kelley K: Amniocentesis prior to 1980. Embryo Project Encyclopedia. Available at http://embryo.asu.edu/handle/ 10776/2072 (2013), accessed May 1, 2018.

15. Sachs L, Fogel M, Winocour E: In vitro analysis of a mammalian tumour virus. Nature 1959;183:663-664.

16. Sachs L, Fogel M, Winocour E, et al.: The in vitro and in vivo analysis of mammalian tumour viruses. Br J Cancer 1959;13:251-265.

17. Krim M, Sachs L: Virus release from single cells of mouse parotid tumours. Nature 1960;186:262.

18. Institute of Medicine (US) Committee to Study the AIDS Research Program of the National Institutes of Health: The AIDS Research Program of the National Institutes of Health. National Academies Press, Washington DC, 1991.

19. Centers for Disease Control: Pneumocystis pneumonia-Los Angeles. MMWR Morb Mortal Wkly Rep 1981;30:250-252.

Address correspondence to:

Rowena Johnston

Department of Research amfAR

120 Wall Street, 13th Floor New York, NY 10005

E-mail: rowena.johnston@amfar.org 